\title{
CIRCUITO DE LEITURA: FORMANDO LEITORES PARA O FUTURO
}

\author{
Bruno Henrique Murisset de Oliveira ${ }^{1}$ \\ Crislene Mescouto da Silva ${ }^{2}$ \\ Christiane Palheta Ferreira ${ }^{3}$
}

\begin{abstract}
RESUMO: $O$ projeto circuito de leitura realizado na escola Consuelo coelho Sousa situada no 40 horas em Ananindeua-PA relata a experiência dos bolsistas do Programa PET/ Conexões de Saberes Diálogo Entre a Universidade e as Comunidades Populares, oriundos de escolas públicas e residentes de comunidades populares. Que tem por objetivo incentivar o prazer pela leitura de alunos do $6^{\circ} 7^{\circ}$ e $8^{\circ}$ ano, do ensino fundamental, como forma de atração pela leitura, escrita e de expressão da criatividade. Nesse sentido demos ênfase no ensino de leitura que proporcionou o desenvolvimento de um trabalho com várias vertentes distintas relacionando suas múltiplas linguagens dentro da concepção da língua em que o ato de ler dar-se entre autor, leitor, texto e contexto, e a partir disso originando-se um leitor ativo que recebe, transforma e age sobre a leitura a língua e a vida.
\end{abstract}

\section{PALAVRAS-CHAVE: CIRCUITO DE LEITURA. INTERACIONISMO. LEITURA. ESCRITA.}

\section{INTRODUÇÃO}

O Circuito de Leitura em sua trajetória no ensino da leitura e escrita surgiu como forma de reforço escolar na instituição familiar e culminou na rede pública de ensino como projeto de pesquisa e extensão em um primeiro momento na escola Consuelo coelho e Sousa no bairro dos 40 horas em Ananindeua e posteriormente estendendo-se para a Escola Celso Malcher localizada no bairro da Terra Firme, em Belém, os quais os bolsistas do programa que são oriundos da rede pública de ensino se deslocam as escolas com o objetivo de desperta o gosto e o prazer pela leitura e a produção de conhecimento.

Nesse contexto, sabemos que a deficiência da leitura no ambiente escolar, se torna bem evidente por vários motivos, que na maioria das vezes se inicia no âmbito familiar no qual a criança e seus familiares não têm a pratica da leitura por motivos adversos e na escola esta prática fica em segundo plano. Nesse sentido e quase

\footnotetext{
${ }^{1}$ Graduando do Curso de Licenciatura em Ciências Naturais da Universidade Federal do ParáUFPA/email:murisset29@yahoo.com.br.

${ }^{2}$ Graduanda do Curso de Licenciatura Plena em Pedagogia da Universidade Federal do Pará- UFPA/ email: crislenemescoutos@yahoo.com.br.

${ }^{3}$ Graduanda do Curso de Licenciatura Plena em Pedagogia da Universidade Federal do Pará- UFPA/ email:christianepalheta@yahoo.com.br.
}

Revista PET Interdisciplinar e Programa Conexões/UFPA On-line. Vol. 01 - 2016. Página 44 
impossível ter a leitura como prática social e como forma de aprendizagem. Buscando intervi nesse problema o projeto circuito de leitura lendo para ser feliz se insere, objetivando o gosto pela leitura como forma de entendimento da leitura, escrita, expressão de criatividade e compreensão do mundo e mais que isso, é impossível adquirir o gosto e o prazer pela leitura para expressá-la de modo criativo, crítico, estético e nas diversas manifestações artísticas culturais. Sem a interação entre autor, texto e leitor o livro nunca será visto como "ato de fala impresso, que constitui igualmente um elemento da comunicação verbal. Ele é objeto de discussões ativas sob a forma de diálogo" (BAKHTIN, 1990, p. 123).

\section{OBJETIVOS}

O projeto circuito de leitura: lendo para ser feliz: tem por objeto ensinar o gosto e o prazer pela leitura dos alunos que participam do projeto fazendo com eles por meio do que vivenciaram possam compreender as palavras e a escrita, bem como compreender o mundo e terem mais criatividade naquilo que vivenciam.

Compreende-se que, para a realização e concretização de tal objetivo - no ensino de leitura e escrita - é necessário partir de uma “concepção interacional (dialógica) da língua, onde os sujeitos são vistos como autores/construtores sociais, sujeitos ativos que - dialogicamente - se constroem e são construídos no texto" (KOCH \& ELIAS, 2011, p. 10).

\section{METODOLOGIA}

No primeiro momento são formados quatro grupos de bolsistas que são enviados as escolas atendidas pelo projeto. Em ambas as escolas a dois horários de atuação dos bolsistas, em turnos da manhã e tarde onde cada grupo tem autonomia para propor suas atividades no ensino de leitura e escrita, pôr meio de planejamento que se dar com o acompanhamento da coordenadora do projeto.

Após esse acompanhamento, os grupos se deslocam para as escolas para um primeiro encontro com os alunos com o objetivo de conhecer a preferência de gêneros textuais, mostrando a importância da leitura e também fazer uma dinâmica de como reconhecer, a estrutura de um livro (nome do autor, título, etc...). Em seguida os alunos são estimulados a fazer um livro fictício relatando uma história criada pelos os mesmo e apresentar aos colegas. É deste primeiro contato e primeira produção textual que se 
desenvolvera o trabalho por meio da leitura dos livros.

A proposta consiste que cada criança tenha contato com os livros (selecionados pelos bolsistas), e que façam suas escolhas para o inicio da tutoria e distribuição dos livros, respeitando a faixa etária e a série das crianças e adolescentes participantes do projeto.

Dando seguimento à metodologia a orientação da leitura do livro e rodas de conversa entre os alunos e seu tutor sobre a história lida; cada criança produz resumo da história que leu; é feita a socialização da leitura do livro com os alunos que leram outros livros; faz-se a troca dos livros e repete-se a dinâmica de ler, dialogar, produzir um texto, socializar e trocar o livro até que todos os alunos leiam três livros; e por fim, as crianças e os bolsistas apresentam a história lida a partir das diversas expressões artístico-cultural no Circuito de Leitura realizado no auditório do ICED/UFPA e na Escola Consuelo Coelho e Souza e no Celso Malcher, em datas distintas.

\section{RESULTADO E DISCUSSÃO}

Os resultados de evolução da leitura das crianças são bem satisfatórios para os bolsistas que participam do projeto, pois os alunos, que em um primeiro contato demonstram insegurança para oralizar a leitura por não ter a prática dessa atividade, já quando estão na leitura do segundo livro estão com a mesma mais dinâmica, no que desrespeito aos aspectos fonéticos e fonológicos da língua, no pensamento, posicionamento da voz e na maneira de socializar a leitura na qual relacionam a história lida com as experiências vividas.

Compreendemos que embora os alunos, em sua maioria, sejam de comunidades populares, não venham de um convívio de leitura efetiva, e, na sua maioria, possuem dificuldades ao ler, ao compreende e ao escrever não significa que elas sejam menos competentes na prática de ler e escrever, nem menos capazes de aprender. Marginalizálas e/ou negligenciar tais competências e a aquisição de muitas outras é, sem dúvida, a única incapacidade e incompetência que ainda é muito frequente na educação de norte a sul do país, por motivos diversos.

Isto implica que a eficácia da produção textual e o domínio da leitura, certamente, não se dão de forma igual para todos, pois cada aluno é e tem suas dificuldades em particular. Deste modo, o trabalho com a leitura em momentos distintos, envolve, além do texto impresso, a leitura de filmes, de vídeos sobre leitura, 
leitura de imagens retiradas de revistas e contação de história pelos bolsistas, como forma de relacionar linguagens, sentidos e obter a adesão de alguns alunos que não queriam participar do projeto e/ou da leitura do texto impresso

\section{CONCLUSÕES:}

Acreditamos que o ato da leitura precisa ser prazeroso para as crianças. E por meio do projeto o que percebemos é que elas passam a ter o prazer e o gosto pela leitura. As leituras em si decerto fazem com que elas tenham novas descobertas, novos encantamentos, já que da leitura obrigatória à leitura escolhida pela criança a uma grande diferença, pois é algo que elas passam a gostar e percebem que isso tem bastante relevância para a vida cotidiana, com isso passam a interagir com o texto, a compreender as múltiplas linguagens e criatividade.

\section{REFERÊNCIAS}

BAKHTIN, M. M. Marxismo e filosofia da linguagem: problemas fundamentais do método sociológico na ciência da linguagem. 5. Ed. São Paulo: HUCITEC, 1990.

KOCH, Ingedore Villaça; ELIAS, Vanda Maria. Ler e compreender os sentidos do texto. 3. Ed. São Paulo: Contexto, 2011. 